\title{
Mýty o prosociálnosti, výchove charakteru a etickej výchove
}

Hoci diskusia o koncepcii etickej výchovy na Slovensku a v Čechách bola predovšetkým v prvých rokoch zavedenia tohto predmetu do štátneho vzdelávacieho programu vel'mi živá, miestami až dramatická, nepokryla celú problematiku výchovy charakteru a paradoxne, nezazneli v nej skutočne najrelevantnejšie argumenty. Namietané boli vybrané charakteristiky koncepcie (kurikulum, metódy, organizácia predmetu), na základe ktorých sa nesprávne indukovali jej korene a až tieto nesprávne identifikované korene boli potom podrobované kritike. Ba čo viac, diskusia vôbec netematizovala základnejšie výhrady voči etickej výchove ako napr. jej zdôvodnitel'nost' v školskom kontexte a ešte viac, vôbec samotný záujem spoločnosti formovat' charakter iného človeka.

$\checkmark$ nasledujúcom texte sa preto budeme zaoberat' tromi skupinami argumentov, ktoré u nás, ale aj vo svete zaznievajú v diskusiách o výchove charakteru. Argumenty reagujú na pomerne ustálené miskoncepcie či nedorozumenia voči etickej výchove a výchove charakteru ako takej. Prvá skupina mýtov (1-3) má konceptuálny charakter - tvoria ju výhrady voči koncepcii etickej výchovy, ktorej ústrednou tézou je výchova k prosociálnosti, a tiež zdanlivej nejasnosti a redundantnosti pojmov cnost' a morálny charakter. Druhú skupinu (4-7) tvoria výhrady voči zdôvodnitel'nosti mravnej výchovy v školskom kontexte. Napokon (8) diskutujeme pozíciu výchovy charakteru $v$ kontexte súčasného stavu majoritnej kultúry $\vee$ severoatlantickom priestore.

\section{Etická výchova je bezobsažný predmet}

Kritika etickej výchovy v tomto bode je analógiou kritiky voči prevažujúcej svetovej školskej kurikulárnej politike zdôrazňujúcej význam kompetencií (OECD, UNESCO a pod.) z pozícií obsahovo zameraného chápania školského kurikula (Kaščák \& Pupala, 2011; Štech, 2013 a i.). V tejto diskusii sa ale (možno napriek očakávaniam) nestaviame na stranu na-kompetenciách-postaveného kurikula na úkor obsahu, avšak nie z dôvodov, ktoré nastoluje S. Štech. Ponúkame tri protiargumenty voči tomuto mýtu.

Najtriviálnejšou odpoved'ou na uvedený bod kritiky by bolo poukázanie na aplikačné tematické celky etickej výchovy (ekologické, ekonomické, rodinné, religiózne 
94 hodnoty, či hodnoty zdravia a ludskej sexuality), ktoré pracujú s konkrétnymi obsahmi. Tieto sú metodicky sprostredkované zážitkovými výchovnými postupmi, projektovým vyučovaním, príp. metódami morálnych dilem, no stále predpokladajú štúdium kontextu mravne relevantného problému (teda odborného obsahu).

Takáto odpoved' by však nebola úplná, pretože by nereagovala na kritiku základného programu etickej výchovy (s tematickými celkami, akými sú napr. rozvoj komunikácie, tvorivosti, empatie, chápanie dôstojnosti ludskej osoby a formovanie zdravej sebaúcty atd'.). Druhým argumentom je preto fakt, že reflexia zážitkových aktivít sústredených na sociálne a eticky relevantné situácie je naplnená špecifickým obsahom humánnych a sociálnych vied. Napríklad úloha dešifrovat’ v medziludskej komunikácii funkciu neverbálnych prejavov vyžaduje konkrétne poznatky o neverbalite človeka; schopnost' asertivity zasa predpokladá popri afektívnych a konatívnych prvkoch tiež kapacitu pre kritické myslenie, argumentáciu a jasnost' formulovania vlastného stanoviska na základe vedomostí z kontextu morálnej dilemy; vedomie vlastnej hodnoty ako súčast' komplexného pojmu sebaúcty sa opiera o vedomosti z oblasti dôstojnosti ludskej osoby, resp. $\mathrm{k}$ nim vedie; schopnost' reflektovat' vlastné citové prežívanie stavia na obohacovaní slovnej zásoby $v$ tejto oblasti a pod. Vo všeobecnosti, nadobudnutie akejkolvek kompetencie vyžaduje obsahový materiál, na ktorom sa rozvíja. Týmto obsahom sú osobné skúsenosti žiakov, kultúrne diela či transdisciplinárne texty. Transdisciplinaritu nechápeme len ako stratégiu tvorby medzipredmetových vzt’ahov, ale ako synergické využitie holistického pohladu na obsah, ktorý je možné konceptualizáciou prepájat' na úrovni konštánt. Prínosom aplikácie konštánt je nielen hlbšie pochopenie vzt’ahov a pojmov, ale tiež sýtenie afektívneho a konatívneho rozmeru textov, ktoré by $v$ predmetovom prístupe mali inak len vel'mi zúžený kognitívny potenciál. Príkladom takejto konštanty je koncept rovnováhy, ktorý možno aplikovat' vo všetkých predmetoch - tak literatúre, matematike, geometrii, biológii, chémii, ako aj vo výtvarnej výchove, občianskej náuke či etickej výchove (ako príklad praxe pozri Grohová, 2018). Etická výchova v rovine všeobecných konceptov teda obsahovo môže spolupracovat's akýmkolvek akademickým predmetom. Napokon, toto konceptuálne prepojenie predmetov sa môže stat' užitočným princípom v aktuálnom procese prepracovávania štátneho vzdelávacieho programu (pozri ŠPú, 2020).

Tretím, najzásadnejším, je však samotný etický argument, ktorý siaha d’aleko za didaktickú diskusiu medzi progresivizmom a esencializmom (porov. Pasch, 1998), teda filozofiami vzdelávania, ktoré stoja za kompetenčným, resp. obsahovým zameraním tvorby kurikula. Argument, o ktorom hovoríme, upozorňuje, že na kompetencie zamerané vzdelávanie podriad'uje výchovu a vzdelávanie imperatívu produkovat' a reprodukovat' na produkciu zamerané poznanie. Hrozí nám, že zabudneme, že človek je morálna bytost', ktorej zámerom je dosahovat' nielen veci užitočné a osožné, ale aj dobré (porov. Mari, 2019, 67-69, in Rajský, 2020). Kým kompetenčné vzdelávanie je možné chápat' ako výcvik, výchova v holistickom mravnom zmysle je formujúce vzdelávanie. Je orientovaná na rozvíjanie humanity človeka, ktorá je personalizovaná, a to originálnym spôsobom pri každom jednom žiakovi. Humánny vzt’ah s druhým nezávisí od uspokojovania potrieb, ale od spoločnej príslušnosti k ludstvu. 
Požiadavka vychovávat' nie je v prvom rade inštrumentálna (niečo získaj), ale etická: staň sa, kým si (alebo nájdi si svoj spôsob, ako naplňat' svoju identitu). Výsledkom je autentické poznanie seba, teda obsah par excellence, a sebariadenie skrze praktickú múdrost' (fronésis) ako cnost'. Kým kompetentný človek vie analyzovat' a riešit' problémy, múdry človek (gr. fronimos) vie posúdit', ktoré problémy sú klúčové, a vie syntetizovat' znalosti koherentne vo vzt'ahu k hodnotám, a to v rôznorodých kontextoch. Kvalita znalosti sa tu líši tak, ako ju diferencovali starovekí Gréci - na techné, epistémé a fronésis. Kým kompetenčné vzdelávanie gravituje k techné a obsahovo zamerané $\mathrm{k}$ epistémé, tak etická výchova smeruje $\mathrm{k}$ fronésis.

Ak teda hl'adíme kriticky na kompetenčné modely vzdelávania a výchovy, nie je to z pozícií rovnostárskych téz, ktoré vidia za kompetenciami neoliberálny nástroj triedneho ekonomického boja, ale z pozícií etiky, ktorá nechce byt' len sekundárnou pomocnou silou pri zefektívňovaní produkcie.

\section{Etická výchova je len aplikovanou psychológiou výchovy k prosociálnosti}

S predchádzajúcim výkladom úzko súvisí odpoved' na d'alší mýtus vzt'ahovaný k etickej výchove, ktorý ju - spájajúc s dielom hlavného inšpirátora koncepcie (Roche Olivar, 1992) - redukuje na aplikovanú psychológiu prosociálnosti (Grác, 2004; Gluchman, 2009; Valenta, 2009). Faktom je, že autori koncepcie etickej výchovy Ladislav Lencz, Ol'ga Križová a ich spolupracovníci, nemali ambíciu explicitne jej výchovný program ukotvit' v konkrétnom filozoficko-etickom systéme. Pri jeho implementácii, vzhl'adom na vel'mi dynamické až turbulentné obdobie krátko po Nežnej revolúcii, zvolili cestu praktického nácviku konkrétneho metodického postupu s dôrazom na jednoduchost' a časovo nenáročnú prenositel'nost' do rôznorodého prostredia slovenských škôl. Hoci však autori neformulovali tieto východiská explicitne, v jadre koncepcie a metodických textoch sú implicitne prítomné isté charakteristiky, ktoré nám napomôžu tieto korene pomenovat'.

Najautentickejším spôsobom je koncepcia etickej výchovy vysvetlitel'ná skrze východiská etiky cnosti, etiky starostlivosti a dialogického personalizmu (porov. Rajský, 2014, 2016; Brestovanský, 2020a), pričom prepojenie etiky cnosti a lásky je unikátnym vkladom Tomáša Akvinského (Wiesenganger, 2018). V úvode k jednému z metodických materiálov etickej výchovy píše O. Križová (2009): „V etike ide o l'udský život ako celok, preto sa pýtame, ako sa správat', aby náš život mal zmysel, aby sa vydaril ako celok, aby priviedol človeka k naplneniu (k št’astiu)“. Toto stanovisko je v skutočnosti typickou formuláciou etiky cnosti, pretože naplnenie (blaženost', gr. eudaimonia, angl. flourishing) je ústrednou tézou aristotelovskej etiky, ktorá je postavená na dosahovaní cností. Inými slovami, eudaimonia je vlastne žitá cnost', citujúc Aristotela (Etika Nikomachova, podla vyd. 1937): „Blaženost' je akási činnost' duše z hl'adiska dokonalej cnosti. “ Na okraj treba pripomenút', že pojem eudaimonie d’aleko eticky presahuje psychologický pojem well-being, resp. vzt'ahuje sa k vel'mi 
96 konkrétnej konceptualizácii tohto pojmu (porov. Déci \& Ryan, 2008). Kritika voči koncepcii etickej výchovy ako príliš psychologizujúcej je preto skôr odrazom istých očakávaní a predstáv kritikov o inom, odlišnom ukotvení koncepcie, než výsledkom hlbokej analýzy praxe etickej výchovy ako prostriedku formácie charakteru žiakov. Kým J. Grác (bližšie pozri 2008) vychádza z neokolbergiánskych pozícií postavených na aplikácii Kantovej deontologickej etiky, V. Gluchman (1996) presadzuje kánon etiky sociálnych dôsledkov. Spoločným je ich dôraz na etické vzdelávanie a intelektualistické aspekty mravnosti. Naproti tomu, etická výchova je aplikovanou etikou cnosti, ktorá sa vyhýba tak moralizovaniu, presnejšie moralistickému omylu, ako aj pozitivistickému deskriptívnemu opúšt’aniu normatívnosti etiky, presnejšie naturalistickému omylu (bližšie pozri Rajský, 2016, s. 19-20).

Etika cnosti sa začala rozvíjat' ako dôležitá alternatíva $k$ dovtedy prevažujúcim deontologickým a utilitaristickým etikám v polovici 20. storočia (Anscombe, 1958; Maclntyre, 1981/2007), neskôr na prelome tisícročí na ňu nadviazala pozitívna psychológia (Seligman \& Csikszentmihalyi, 2000). Nielenže sa obnovil všeobecný záujem o cnosti a plnohodnotný zmysluplne prežitý život (eudaimoniu), ktoré - treba pripomenút' - boli až do nástupu osvietenstva klúčovými pojmami etiky, ale na scénu tiež vstúpila problematika morálnej identity a morálneho charakteru, teda nová komplexnejšia paradigma l'udskej morality. Podla anglického morálneho filozofa B. Williamsa (in Palovičová, 2003) kognitivistické etické teórie sa dopúšt’ajú omylu tým, že zo zorného pola posudzovania morálnych činov im vypadávajú podmienky života, v ktorých človek koná a ktoré formujú charakter. Tvrdí, že etiky pravidiel utilitarizmus a kantovstvo - redukujú naše chápanie morálnej skutočnosti tým, že ich morálne názory sú postavené na predstave neosobnej morálky a abstraktnej osoby, stotožnenej s racionálnou osobou. Potom mysliet' a konat' morálne zaväzuje človeka, aby sám seba abstrahoval od všetkých svojich sociálnych špecifík a od zaujatosti, bol nedotknutel'ný citom a nemal počítat' s vlastnými záujmami. Abstraktné morálne teórie podla tohto autora vynechávajú či odmietajú dôležité morálne fenomény a fundamentálne fakty ludskej motivácie.

Aristotelovská výchova charakteru sa zameriava na rozvoj praxe v konaní dobra. Výchova nie je len aplikáciou morálnej teórie, nejde tu prioritne o mravné vzdelávanie. Koncepcia sa niekedy dokonca môže javit' ako redukujúca morálnu filozofiu. Podla Aristotela je však dôležitejšie vediet', ako sa cnost' prakticky nadobúda, než mat' exaktné vedomosti, čo termín cnost' presne znamená.

Etická výchova pracuje práve s takto aristotelovsky chápaným živým kontextom jednotlivého človeka a spoločenstva, pričom normou sú pre ňu ideály cnostného priatel'stva, ktoré je definované skrze koncept prosociálnosti. Prosociálnost' $v$ koncepcii etickej výchovy je teda definovaná užšie (a hlbšie) v porovnaní s bežnými definíciami prosociálneho správania (porov. Eisenberg, Fabes, \& Spinrad, 2006; Bierhoff, 2002 a i.), ked'že tento etický ideál priatel'stva premieta do podmienky rešpektovania morálnej integrity druhého.

V skratke, koncepcia etickej výchovy je vo svojom jadre pôvodnejšia než sú novoveké koncepcie a so svojím praktickým naturalizmom je žiakom bližšia než 
intelektualistické koncepcie vychádzajúce z deontologických, resp. utilitaristických teórií.

\section{Morálny charakter a cnost' sú nejasnými, zastaranými a redundantnými pojmami}

V porovnaní s jasne terminologicky ukotvenými prírodnými a technickými vedami, ktoré utvárali „ideál objektivity výskumu založený na čo možno najdokonalejšej matematizácii javov“ (Janík, 2017, s. 28), v sociohumánnych vedách vládne v porozumení pojmov dynamika vyplývajúca z bytostnej subjektivity (fenomenálneho) vedomia. V týchto vedách neexistujú metrické platinové etalóny uložené v Pariži zastupujúce normu toho-ktorého pojmu. Zohl'adnenie l'udskej jedinečnosti ostrejšie konfrontuje sociohumánne vedy s problémom objektivity (ibid.). V problematike porozumenia komplexných pojmov napr. existujú vedecké postupy snažiace sa o zist'ovanie prototypických štruktúr, kognitívnych reprezentácií v jednotlivých sémantických kategóriách (Rosch, 1975). V oblasti skúmania cnosti napr. Morganová a kol. (2014) ukázali, že pojem vd’ačnosti je aj v bežnej reči prototypicky organizovaný, t. j. v dvoch nezávislých výberoch respondentov z rôznych krajín má vel'mi podobnú štruktúru prívlastkov. Napriek tomu však stále v sociohumánnej realite bude pretrvávat' istá nutná pojmová nejednoznačnost'. Preto je nutné terminologicky tieto termíny a ich pojmy voviest' do akademického diskurzu v konkrétnom konceptuálnom rámci.

A to v situácii, ked' v knižnej literatúre používanie slov, ktoré reprezentujú cnosti, medzi rokmi 1901 až 2000 kleslo o 74 \% (sledované na vzorke 5,2 milióna digitalizovaných kníh, Kesebir \& Kesebir, 2012). K. Kristjánsson (2013) sa pýta: ak sme zaznamenali takýto pokles používania pojmov v oblasti morálneho charakteru a cnosti, čím boli nahradené? Populárnymi sú podla neho psychologické modely popisujúce základné osobnostné črty, ako napr. Big Five: otvorenost', svedomitost', extraverzia, prívetivost' a neurotizmus (McCrae \& Costa, 1987). Napriek tomu, že model bol koncipovaný bez snahy nahrádzat' morálny obsah, existujú tendencie najmä pojmy svedomitost' a prívetivost' interpretovat' s presahom do konceptu cnosti. Takýto postup však oslabuje to, čo je pre naše Ja klúčové. Je v ňom príliš vel'a „svojvôle“, pokial' ide o popísanie vlastností, ktoré z nás robia „toho, kým sme“ v každodennom zmysle. Napr. dimenzia svedomitosti sa vzt'ahuje k disciplinovanosti, spolahlivosti a predvídatel'nosti správania. Žiadna z týchto charakteristík nenesie morálne konotácie; aj člen zločineckej skupiny môže disponovat' takýmito črtami. Tým sa výrazne tento pojem v kontexte Big Five líši od svedomitosti ako morálnej cnosti, ktorá je spravidla súčast'ou širšieho zvažovania praktickej múdrosti fronésis o dobre. To isté sa dá povedat' o prívetivosti. Napr. v kontexte prístupu učitel'a k žiakom musíme rozlišovat' odmoralizovaný pojem vyučovacieho štýlu (tzv. interakčný štýl učitela) od učitelových mravov (manner), ktoré odkazujú na morálnu rovinu v jeho správaní (Kristjánsson, 2013). Podobne d’alšie psychologické konštrukty ako pojem o sebe, sebaúcta, sebaregulácia či vnímanie profesijnej zdatnosti môžu mat' tendenciu byt' 
98 interpretované ako nahrádzajúce pojem cností. Opät', tieto pojmy nepokrývajú celú bohatost' cnostného života či spektra cností. So zistením sestier Kesebirových súvisí tiež možný dojem staromódnosti terminológie o cnostiach a morálnom charaktere ako niečoho stredovekého. Opak je však pravda. V súčasnosti sledujeme silný nástup etiky cnosti reprezentovaný tak vo filozofii (Anscombe; Maclntyre; Annas, Kristjánsson a i.) ako aj v (pozitívnej) psychológii (Seligman, Peterson, Snyder a i.). Podobný vývoj sa ukazuje tiež $v$ bežnom ludovom diskurze: $v$ jednom $z$ najväčších výskumných projektov v oblasti výchovy charakteru (Arthur, 2010) na výbere 70 tisíc respondentov zistenia ukazujú nielen to, že mladí ludia sa zaujímajú o vlastný charakter a nadobúdanie dobrých vlastností, ale najmä to, že sami sú si vedomí svojho nedostatku slovnej zásoby, aby mohli o týchto témach zmysluplne hovorit', ale ked' sa im napomohlo k rozšíreniu relevantnej slovnej zásoby, ocenili to a s potešením ju používali.

V skutočnosti preto pojem cnost' nemožno celkom dobre nahradit' žiadnym iným, hoci sú v rôznych diskurzoch používané jej rôzne ekvivalenty (charakterová črta, dispozícia, návyk, či dobrá vlastnost', zdatnost' človeka a pod.).

Aristoteles o cnosti tvrdí, že ide o získanú vlastnost', zvolený stav - habitus, je to stred medzi dvoma krajnost'ami, je to konanie $v$ súlade $s$ praktickým rozumom (gr. fronésis), je to vol'ba prostriedkov, ale aj ciela, ktorý je dobrý - dôsledkom takého konania je život naplnený blaženost’ou. Cnost' ako pretrvávajúci stav nás disponuje l'ahšie sa rozhodovat' v situáciách, ktoré vyžadujú rýchle rozhodovanie, a zároveň tieto rozhodnutia sprevádzajú súhlasné emócie, t.j. nekonáme dobro s odporom, ale toto konanie nám prináša radost' a spokojnost'. „Cnost' je excelentná črta charakteru, ktorá pomáha všimnút' si, očakávat', ocenit', cítit', túžit', konat' a reagovat' určitým charakteristickým spôsobom, a to v rôznych odlišných situáciách" (Arthur et al., 2017). Cnost' však nie je inherentná stála dispozícia alebo nehybná črta osobnosti v zmysle nemennej danosti. Cnost' sa skôr nadobúda skrze prax, pričom vzniká tendencia žit' určitým spôsobom. Je aktívna - mat' ju znamená byt' disponovaný konat' určitým spôsobom a vyvíja sa - skrze špecifické reakcie a odpovede v konkrétnych podmienkach. Možno vhodnejším termínom než „stála“ je preto termín „pretrvávajúca“" v zmysle odolná vo výzvach a t’ažkostiach, pričom rastie alebo klesá na sile práve cnostným alebo necnostným konaním. Cnost' je tiež reliabilná (spol’ahlivo očakávatel'ná), bolo by pre nás prekvapivé, ak by sa napríklad súcitný človek zachoval zrazu voči druhému tvrdo, a hladali by sme alternatívne vysvetlenia. Ide teda o hlbokú črtu, ktorá spoludefinuje charakter človeka, t.j. mení jeho osobnost' (Annas, 2011). Cnost' nás uschopňuje, aby sme dosiahli dobrá, ktoré sú inherentné v rámci určitej praxe (Maclntyre, 2007). Autor rozlišuje dva druhy dobier - inherentné a externé - náhodne pridružené $k$ praxi, t.j. patriace $k$ nejakej činnosti len $v$ konkrétnej udalosti a $v$ konkrétnych sociálnych okolnostiach. Klasickými príkladmi externých dobier sú moc, status, sláva, prestíž či peniaze. Teda na rozdiel od inherentných dobier tieto možno dosiahnut' aj nezávisle od danej praxe. Inherentné dobro je viazané na príslušnú prax, teda každá prax poskytuje dobrá charakteristické pre túto jednotlivú prax, a tieto dobrá nemožno získat' inak ako účast'ou na danej praxi. 


\section{Etická výchova je len menej kvalitným až neodborným psychosociálnym výcvikom}

Na rozdiel od predchádzajúcich troch koncepčných výhrad, táto má skôr praktický charakter, silne však nadväzuje na mýtus o neetickosti etickej výchovy ako psychológii výchovy k prosociálnosti. V etickej výchove hrá mimoriadne dôležitú úlohu fáza morálnej reflexie, ako jedna z koncepčne definujúcich fáz vo vyučovacom procese tohto predmetu (porov. Podmanický, 2012). Práve morálno-reflektívna funkcia ju zásadne odlišuje od psychosociálnych výcvikov a podobných intervencií. Zároveň ale platí, že táto fáza patrí spravidla $v$ praxi k najslabšie zvládaným zo strany učitelov (Podmanický \& Brestovanský, 2018; Valica et al., 2014). Preto sme vypracovali model implementácie troch domén morálnej reflexie do koncepcie etickej výchovy.

Etika cnosti je v modeli reprezentovaná hlavnou premennou kvality morálnej reflexie - pojmom fronésis - a prvkami, ktoré sme vysvetlili vyššie. Praktická múdrost' je zastrešujúcim pojmom celého procesu morálneho usudzovania, vyjadruje súbor charakteristík, vd’aka ktorým je žiak schopný s pomocou učitela vnímat' celý kontext a jeho jednotlivé diferencujúce detaily. Zabraňuje zúženému pohladu na situáciu a neadekvátnemu uprednostňovaniu jednej exkluzívnej cnosti. Jej prejavom je tiež schopnost' sebareflexie, čo vytvára predpoklady pre metakognitívne usudzovanie žiak je vedený $\mathrm{k}$ tomu, aby si v procese morálneho uvažovania uvedomil svoje vlastné tendencie $v$ uvažovaní a prípadné racionalizačné stratégie, ktoré môžu mat' pôvod $\checkmark$ nespracovaných emóciách a pod. Dialogický antropologický princíp zasadzuje toto uvažovanie do vzt’ahovej podstaty života človeka (Buber, 2002). Každú morálne relevantnú situáciu teda etická výchova rieši z pohladu, ako sa jej riešenie dotýka druhého, jeho dôstojnosti či možností jeho duchovného rastu. K tomu sa pridružuje empatia ako schopnost' nazerat' na situáciu z perspektívy druhého, rozumiet' jeho celkovému kontextu a spolucítit' s jeho prežívaním.
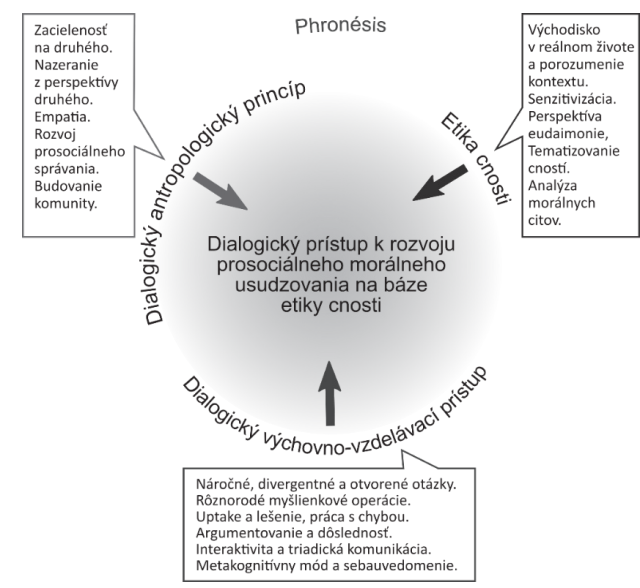

Obr. 1 Tri domény morálnej reflexie v koncepcii etickej výchovy 
Dialogický výchovno-vzdelávací prístup je didaktickým prejavom týchto dvoch domén. Poskytuje konkrétne nástroje, indikátory, ktorými je možné skvalitňovat' a výskumne sledovat' samotný vyučovací proces (porov. Alexander, 2006; Šed'ová et al., 2016).

Súhra popísaných troch domén vytvára špecifický dialogický prístup v rámci morálnej reflexie v koncepcii etickej výchovy ako výchovy cnostného charakteru. Principiálne sa tým odlišuje od odmoralizovaných prístupov psychosociálnych intervencií.

\section{Morálnemu charakternému správaniu nie je možné naučit' vo formálnom prostredí, takýto zámer nepatrí do škôl}

Napriek tomu, že medzi bežnými lud'mi je takéto tvrdenie vel'mi zriedkavé, naopak, od školy očakávajú posilnenie jej výchovnej funkcie (Focus, 2015), budeme sa týmto mýtom zaoberat', pretože ide o vážnu morálno-praktickú otázku, ktorá rozdel'uje akademikov pohybujúcich sa na rozmedzí etiky, psychológie a pedagogiky. Svojím spôsobom ide o prehĺbenie večnej diskusie o priepasti medzi morálnym vedomím/ poznaním a vôlou/aktivitou so zasadením do školského kontextu.

Odpoved' má niekol'ko rovín: a) teoreticko-empirickú; b) koncepčnú a c) metodickú. $V$ teoreticko-empirickej rovine riešime problém jednotlivých komponentov morality a ich rôznej miery formovatel'nosti. $V$ koncepčnej rovine hovoríme o vzt'ahu cielov predmetu etická výchova $\mathrm{k}$ d'alším školským predmetom a k celkovej kultúre školy. A napokon v metodickej rovine hovoríme o pedagogickej efektívnosti v napíňaní týchto cielov.

$\checkmark$ teoreticko-empirickej rovine diskutujeme kontinuum pohl'adov na rolu kognícií až emócií a intuície v konkrétnom procese od morálneho uvažovania k morálnemu činu. Na jednej strane škály stoja, ako sme uviedli vyššie, staršie morálne intelektualistické teórie vychádzajúce $\mathrm{z}$ deontologických, resp. utilitaristických teórií. $\mathrm{Na}$ druhej strane intuitívne teórie s klúčovou rolou aktuálne prežívaných emócií (Haidt, 2001, 2003).

V porovnaní s týmito krajnými pozíciami etika cnosti vedie ku komplexnému pohl'adu na moralitu človeka, ktorý môžeme nazvat' morálny charakter, ktorého súčast'ou je morálna identita a morálne city. Úplne rozvinutá cnost' je stav, ked' sa inteligencia cnosti stáva súčast'ou motivačnej štruktúry osobnosti ako jeho stály návyk v správaní ladiaci s jeho vnútorným prežívaním - človek robí správne veci zo správnych dôvodov. Bergman (2002) v tomto duchu tvrdí, že nezradit' vlastnú morálnu identitu má pravdepodobne ovel'a väčšiu motivačnú silu napomáhajúcu žit' čestný a mravný život, než nezrádzat' akési abstraktné morálne princípy. Bergman kritizuje Kohlberga, že motiváciu prakticky zahrnul pod kategóriu kognícií. Naopak, Blasi po sérii výskumov uzaviera, že „to, čo je potrebné, je určitá integrácia morálneho porozumenia jedinca do jeho osobnosti“ (Blasi, 1989, in Bergman, 2002, s. 119). Inými slovami, prechod od úsudku o vlastnej morálnej zodpovednosti ku konaniu je 
dynamicky podporovaný tendenciou k dosiahnutiu seba-konzistencie, teda základnou tendenciou $v$ organizácii osobnosti. Lapsley to popísal krátko a výstižne:

Pre Kohlberga morálna motivácia konat’ pochádza z vernosti človeka voči normatívnej povahe morálnych princípov, preto nekonat' znamená zradit' princíp. Na rozdiel od neho, pre Blasiho morálna motivácia konat' je dôsledkom vlastnej morálnej identity, teda nekonat' morálne znamená zrádzat' vlastné self (Lapsley, 1996, in Bergman, 2002, s. 120).

Darnellová a kol. (2019) však idú ešte d’alej a všímajú si, že tento model morálneho self síce dokáže vysvetlit' vel'a zo vzt’ahu morálneho usudzovania a morálneho konania, ale predsa tu zostávajú niektoré neobjasnené záležitosti. Po prvé, je t’ažké aplikovat' tento model na typy správania, ktoré sú automatické alebo menej úmyselné, či dokonca sú genetický predprogramované. Po druhé, nezohladňuje, kedy a za akých okolností bude konkrétna identita prežívaná, teda podceňuje efekty kontextuálnych a situačných faktorov. Súčasné sociokognitívne prístupy postúpili v skúmaní a $v$ snahe vysvetlit', prečo niektoré morálne činy môžu byt' tacitné a automatické a ako sa u človeka môžu objavovat' rozličné aspekty seba samého naprieč rôznymi situáciami. Klúčovým aspektom je, že ústrednost' (centrálnost') morálnej identity toho-ktorého človeka sa vzt'ahuje na dostupnost' tzv. schém (Aquino \& Reed, 2002; Cantor, 1990, in Darnell et al., 2019). Schémy sú konceptualizované ako poznatkové štruktúry uložené v pamäti, zahŕňajúce hodnoty, rysy, ciele či scenáre správania. $S$ vel'kou pravdepodobnost'ou sa v konkrétnom kontexte vyberú l'ahko (alebo l'ahšie) dostupné schémy, ktoré budú následne viest' pozornost' človeka smerom k tým relevantným črtám situačných a životných úloh, ktoré budú s nimi v súlade, čo d’alej posilňuje dispozičné tendencie utvorené v týchto schémach. Z tohto hladiska je jednotlivec so silnou morálnou identitou človekom so stále dostupnými a lahko aktivovatel'nými morálnymi schémami. Pre morálnu osobu je potom morálna identita ústredným prvkom jej sebaobrazu a zároveň tieto morálne schémy sú spomedzi všetkých najlahšie dostupné na interpretáciu sociálneho kontextu a konkrétnej udalosti (Darnell et al., 2019). Etická výchova svojimi senzibilizačnými podnetmi, zážitkovým prístupom a morálnou hodnotovou reflexiou umožňujú takéto schémy vytvárat', pričom jej metóda a základné tematické celky napomáhajú tento proces zladzovat' tiež afektívne.

Morálne emócie majú vzt’ah k morálnemu usudzovaniu a konaniu z niekol'kých hladísk:

1. Majú vplyv na konštituovanie morálneho usudzovania v ontogenéze. Môžeme hovorit' o bytostnom hladisku, ktoré sa prejavuje prítomnost’ou adekvátnych emócií v daných morálne relevantných situáciách, v ideálnom prípade (prítomnosti cnosti) súladom morálneho správania sprevádzaného spravidla radost’ou a spokojnost’ou napriek utrpeniu, či rôznym osobným nákladom. Ak sa aj v kontexte neo-aristotelovskej etiky cnosti hovorí o morálnej emócii, spravidla sa myslí tento typ emócie ako osobnostnej črty.

2. Ovplyvňujú morálnu kompetenciu v konkrétnej situácii (defenzívne vs. zvládajúce stratégie riešenia morálnych konfliktov). 
102 3. Samy vyvolávajú morálne konanie, ako napr. morálne city viny či naopak, schopnost' empatie a súcitu.

Bežná zručnost' môže byt' vykonávaná aj nezávisle od zvlášt' afektívneho prežívania konajúceho. Zručný remeselník môže produkovat’ svoje výrobky bez toho, aby sa na ne alebo na samotnú prácu zvlášt' citovo koncentroval. $V$ jeho prípade ide o akúsi rutinu. Na rozdiel od neho, cnostná osoba nebude nikdy konat' cnostný skutok bez zaujatia a s nedostatkom všímavosti. Cnostná osoba nielenže robí správne veci správnym spôsobom, ale prežíva $v$ tom aj správne (adekvátne) city. Napríklad diet’a sa môže $v$ priebehu života učit' delit' sa s ostatnými, no na začiatku to bude robit' len z dôvodu uposlúchnutia autority, rodičov či vychovávatel'ov. Až neskôr, ako sa stáva cnostným, učí sa schopnosti delit' sa autonómne. Avšak, ak u neho bude pretrvávat' resentiment prameniaci z „,nutnosti“ delit' sa, napr. hnev alebo závist', hoci navonok nevyjadrený, nemôžeme hovorit' o cnosti. Ako píše Aristoteles (1937, II/2), za znak cnostného stavu „treba považovat' cit lúbosti alebo nelúbosti spojený s výkonom; ten totiž, kto sa zdržuje telesných pôžitkov a práve z toho sa raduje, je umiernený, kto však nad tým pocit'uje nelúbost', je neviazaný“. Akokolvek, ked'že city sú z definície nevôlové aktivity, môžeme ich formovat' len sekundárne - trvalým opakovaním dobrej praxe $\mathrm{v}$ procese výchovy diet'at'a a naviazaním tejto praxe na pozitívne city. Úlohou rodičov a vychovávatel'ov teda nie je len dosiahnut', aby deti a žiaci konali dobré a morálne veci, ale spolu s nimi sa z takýchto úspechov aj tešit'.

Potenciál predmetu sa však môže výrazne posilnit' v takej kultúre školy, ktorá umožňuje modelovanie morálnych cnostných postojov cez vlastnú školskú kultúru, širokospektrálne programy dobrovol'níckej angažovanosti detí, spoluprácu školy so širšou komunitou a pod. Škola môže rozvíjat' charakter skrze vlastný étos bez toho, aby o charaktere povedal ktokolvek čo i len slovo. Alebo inými slovami,

deti, ktoré doposial' nedospeli k dobrým návykom, potrebujú byt' vystavené istému druhu transformatívnych síl, ktoré im umožnia urobit' radikálnu sebapremenu. Konkrétne, potrebujú, aby samotní učitelia vytrvalo pre nich predstavovali morálne príklady (Kristjánsson, 2015, s. 116).

Výchova charakteru ide teda d'aleko za formálne kurikulum a to, čo má učitel' v zámere obsahovo predstavit'. Etická výchova však môže moderovat' tieto tacitné procesy a byt' priestorom ich explicitnej reflexie.

\section{Výsledky výchovy charakteru ako takej sú nemeratel'né}

S predchádzajúcim problémom súvisí aj nasledujúci. Ak totiž požadujeme výchovu charakteru v školách, mali by sme byt' schopní ukázat' dopad výchovno-vzdelávacích programov a d'alších školských premenných na morálny charakter žiakov. Odpoved' na tento vážny metodologický problém má takisto niekol'ko rovín (Brestovanský, 2020a). $\checkmark$ prvom rade ide o existenciu vel'kého množstva rôznych skrytých premenných, ktoré 
pôsobia $v$ bežnom životnom kontexte skúmaného človeka, $v$ ktorom jedinom sa cnost' ( $v$ aristotelovsky naturalistickom chápaní) autenticky ukazuje. Tento kontext má zásadný význam a škola naň má len slabý dosah (hoci, treba podotknút', niektoré školy posilňujú svoj výchovný zásah cez tvorbu širšej komunity s rodičmi a d’alšími signifikantnými druhými).

Základnou rovinou je tak samotný problém replikovatel'nosti výskumov $v$ sociálnych vedách (Schooler, 2014), ktorý dospel až do stavu replikačnej krízy. Na tomto mieste nie je priestor samostatne sa tejto vel'kej téme venovat'. Uzavrieme len, že zatial' najviac prijímaným východiskom z tohto problému je realizácia masívnych metaštúdií.

Zaznievajú tiež hlasy, žeby sme mali celkovo opustit' nadvládu „evidence-based“ politiky či tzv. „what-works“ " prístupu ${ }^{22} v$ pedagogickom výskume a nahradit' ho tzv. value-based prístupom (Biesta, 2007). Avšak je možné, že toto volanie nesprávne identifikovalo problém, o ktorý tu ide. Ako tvrdí Kristjánsson (2015), problém nie je $\checkmark$ „scientifikácii“ vzdelávania skrze záujem o kontrolované merania výstupov výchovy charakteru tak ako je to v iných vzdelávacích obsahoch. Chyba teda nie je v samotnom prístupe evidence-based, ale skôr v tom, že zo zist'ovania vylučuje inherentné hodnoty ako validné dáta. Takýto prístup nerozlišuje, že existujú l'udské úsilia, ako napríklad cnostné skutky, ktoré majú hodnotu samé osebe a nemusia byt' konané $s$ nejakým d'alším účelom. $V$ tomto zmysle, na rozdiel od pozitivistického prístupu, merania aristotelovskej cnosti sa nemusia spoliehat' na inštrumentálny dopad vzdelávania na premenné nezávisle od osoby, ktorej cnost' je zist'ovaná, v duchu reduktívneho operacionalizmu. Napr. umiernenost' v jedle má inú hodnotu a parametre kvality pre vrcholového športovca a inú pre kuchára. Lepšie „objektívne“ skóre športovca tu vzhladom na rozličný životný kontext nezohráva rolu $v$ zmysle porozumenia úrovne cnosti umiernenosti.

Druhým zjavným problémom merania akejkolvek morálnej domény je sebariportný charakter väčšiny meraní. Nejde len o sociálnu želatelnost' odpovedí, ale aj o nepresný pojem o sebe. Väčšina štúdií, ktoré mali komplexnejší (triangulačný) dizajn, ukazuje silnejšie subjektívne sebanadhodnocovanie v porovnaní s hodnotením od iných ludí (Warden et al., 2003; Brestovanský et al., 2015), pričom u chlapcov býva tento rozdiel v prospech sebahodnotenia ešte vyšší (Fabes \& Eisenberg, 1998). Avšak ani triangulácia meraní nie je zárukou objektívnosti zistení, pretože obraz človeka, aký si o ňom utvorili druhí, takisto nemusí odrážat' jeho autentické Ja, čo platí zvlášt' pri takom fenoméne, akým je cnost', ktorej pravost' určuje až súlad vnútorného preživania a emócií s dobrým konaním.

Pri zist'ovaní a popisovaní tak komplexného pojmu, akým je charakter človeka, v zmysle úrovne nadobúdania rôznych cností v ich všetkých komponentoch, vyžaduje validita skúmania masívny multi-inštrumentálny dizajn, v ktorom sa budú kombinovat' a triangulovat' dáta zo sebariportných dotazníkov, rovesníckych výpovedí a nominácií, dát rodičov či iných dospelých s dátami z iných metód - pozorovaní, interview,

22 So zjavným odkazom na známu vel'kú štúdiu Berkowitza a Bierovej (2005). 
104 vrátane hermeneutického bádania a kognitívnymi úlohami (riešenia morálnych dilem či komplexných úloh). Špeciálne miesto získavajú v ostatnom období neurovedecké metódy, najmä sledovanie mozgových aktivít $v$ čase morálneho uvažovania a rozhodovania (Sevinc \& Spreng, 2014).

Batéria, ktorú navrhujeme, by podla nášho názoru mala obsahovat' sledovanie tak praxe prosociálneho správania, prítomnosti typov cnosti, konceptov morálneho usudzovania a najmä schopnosti riešit' komplexné morálne situácie flexibilne prispôsobené situačnému kontextu respondenta. Popri známom VIA-Youth inštrumente (Park \& Peterson, 2006) je pre nás tak zaujímavý Ad-ICM (Thoma, Derryberry, \& Crowson, 2013) - nástroj pre meranie sprostredkujúcich konceptov, či testy prosociálneho morálneho uvažovania (Carlo et al., 1992; Brestovanský et al., 2016). Slubným posunom (zatial' $v$ ranej fáze vývoja) ku komplexnému konštruktu cnosti napr. v porovnaní so známym neokolbergiánskym DIT2-testom (Rest et al., 1999) je práca H. Curzera a kol. (2014), ktorí po kritickej reflexii DIT2 testu navrhli a overili vlastnú konštrukciu tzv. SMARTS testu. Test umožňuje respondentovi v prvej fáze zvolit' a vysvetlit' morálnu teóriu, ktorá stojí za jeho rozhodnutím v konkrétnej dilematickej situácii (sofistikované teórie: utilitarizmus, deontológia a etika cnosti; sofomorické: egoizmus, relativizmus a etika starostlivosti; spoliehanie sa na autoritu). Problém vytvoreného nástroja je, že bol validizovaný na vzorke vysokoškolských študentov a pre evalvačné použitie $v$ prostredí základných a stredných škôl zatial' neexistuje primeraná veková adaptácia. Zároveň úroveň reliability jednotlivých dimenzií bola relatívne nízka.

Mimoriadne inšpiratívnou pre skúmanie praktickej múdrosti ako klúčovej cnosti je štúdia Brienzu a jeho spolupracovníkov (2017). Po kritike väčšiny doterajších nástrojov, ktoré trpia istou mierou zaujatosti, ich hlavným prínosom je, že presunuli skúmanie múdrosti od použivania globálnych, dekontextualizovaných dotazníkov k postupom citlivým na aktuálny stav a kontext $v$ rámci konkrétnej situácie. Ako reprezentácie múdreho uvažovania definovali konštrukty ako napr. intelektuálnu pokoru, uznanie neistoty a zmien, zváženie širšieho kontextu a perspektív druhých, integráciu týchto perspektív / kompromis a pod. Výsledky ich rozsiahleho psychometrického skúmania $(N=4463)$ ukázali, že nová škála situačného múdreho uvažovania (SWIS) je reliabilná a zdá sa, že je nezávislá od psychologických skreslení (atribučné chyby, zaujatost', sebaklam, vyvolávanie dojmu a pod.).

\section{Výsledky etickej výchovy ako školského predmetu sú zanedbatel'né}

V prvom rade treba priznat', že doposial' neexistuje nástroj, ktorý by komplexne dokázal merat' dopady etickej výchovy $v$ školskej praxi. Nie je ani ujasnené, ako by malo byt' napĺnanie jednotlivých ciel'ov $v$ inovovanom ŠVP, resp. $v$ jeho dodatku, pre etickú výchovu operacionalizované a čo a v ktorých $z$ vyššie pomenovaných komponentov morálneho charakteru je $v$ skutočnosti rozumne očakávatel'né, aby 
etická výchova naplnila. Problém vyhodnocovania výsledkov etickej výchovy je teda syntézou problémov analyzovaných $v$ predchádzajúcich dvoch statiach tohto článku a pri jeho riešení bude pravdepodobne nutné sa uspokojit' $s$ istými parciálnymi ukazovatel'mi, ktoré nepokryjú všetky potenciálne dopady etickej výchovy, resp. celoškolského programu výchovy charakteru, ktorý etická výchova môže moderovat'.

$\checkmark$ rámci uvedených limitov však dokážeme na základe doterajších výskumných projektov poskytnút' prínosné dáta a analýzy ohl'adom dopadov etickej výchovy na skúmané premenné.

Zdá sa, že samotný predmet etická výchova má vplyv na prosociálne správanie za predpokladu priaznivého naplnenia d’alších podmienok. Klúčovými sa tu popri samotnom programe a metódach javia byt' oblúbenost' predmetu a vzt'ah žiaka $\mathrm{k}$ učitel'ovi etickej výchovy, čo napokon platí pre akýkolvek školský predmet.

Napriek tomu, že výsledky komparácie kontrolnej a experimentálnej skupiny v longitudinálnom dizajne nášho výskumu neukazujú zásadné rozdiely, vo vnútri samotnej experimentálnej skupiny nachádzame silné odlišnosti vzhladom na sprostredkujúci význam vyššie uvedených dvoch premenných pre rast prosociálneho správania a prosociálneho morálneho uvažovania. Vo všetkých kategóriách išlo o silné signifikantné rozdiely medzi horným a dolným kvartilom žiakov z pohladu ich subjektívneho hodnotenia etickej výchovy . Môžeme uzavriet', že internalizované prosociálne morálne uvažovanie, zmysel života a hodnotenie etickej výchovy sú v spoločnom modeli signifikantnými prediktormi prosociálneho správania $v$ dvoch za sebou sa opakujúcich meraniach $\left(F(3,121)=12,75 ; p<0,001 ; R^{2}=0,24\right.$ v roku 2015 a $F(3,253)$ $=25,22 ; p<0,001 ; R^{2}=0,23 \vee$ roku 2017) (Brestovanský, 2020b).

$\checkmark$ posledných dvoch vlnách výskumu (8. a 9. ročník ZŠ) sme do dizajnu zakomponovali tiež skúmanie vzt’ahu žiakov $\mathrm{k}$ učitel’om skrze nástroj interpersonálneho správania učitelov (Gavora, Mareš, \& Den Brok, 2003; Vašíčková, 2015). Zistili sme silné korelácie medzi hodnotením etickej výchovy zo strany žiakov a ich hodnotením interakčného štýlu učitel'a (EV-organizačný štýl: $r=0,618$; EV-napomáhajúci: $r=0,582$; EV-nespokojný štýl: $r=-0,548$ a pod., všetky pri $p<0,001)$. Výsledky tiež podporuje regresná analýza vzt'ahu hodnotenia ETV a organizačného interakčného štýlu $\left(F(1,253)=135,65 ; p<0,001 ; R^{2}=0,346\right)$.

Všetky pozitívne štýly hrajú kruciálnu rolu v kreovaní pozitívneho vzt’ahu žiaka k etickej výchove a naopak, všetky negatívne prejavy vážne narúšajú tento vzt’ah. Platí tiež, že interakčný štýl dokáže učitel' intencionálne menit'. Zmeny boli (pravdepodobne vd'aka zvýšenému úsiliu učitel'ov v priebehu projektu) s odstupom roka signifikantné, ale len $v$ experimentálnej skupine. $V$ nej mali učitelia vyššie skóre $\checkmark$ organizačnom $(p<0,05)$, pomáhajúcom $(p<0,01)$, chápajúcom aj zodpovednom $(p<0,001)$ prístupe a nižšie $v$ karhajúcom $(p<0,01)$. $\vee$ našom experimentálnom dizajne sme navyše $v$ poslednom roku ešte experimentálnu skupinu rozdelili na podskupiny $A$ a $B$, pričom skupina učitelov $A$ dostávala $v$ priebehu roka dodatočnú metodickú podporu (na základe analýzy videí z vyučovania). Korelácie medzi hodnotením ETV a zodpovedajúcimi typmi prosociálneho morálneho uvažovania sú $v$ tejto skupine najsilnejšie, navyše, hoci žiaci v experimentálnej skupine už v pre-testoch 
dosahovali vyššie skóre internalizovaného prosociálneho morálneho uvažovania, nárast skóre v tomto vývinovo najvyššom type bol u nich najväčší.

\section{$8 \mathrm{~V}$ post-postmodernej spoločnosti je akákol'vek výchova charakteru ideologickým násilím, príp. je v podstate anti-demokratická a anti-intelektuálna}

Paradoxné je, že koncepcia etickej výchovy je kritizovaná tak zlava, zo strany progresívnych politík, ako aj sprava, zo strany konzervatívnych autorov. Prvé výhrady sa týkajú dôrazu koncepcie na cnost', t. j. inými slovami spoločensky nedeterminovanú morálnu slobodu, proaktivitu a sebariadenie človeka. Z pohl'adu progresivistov, príp. neo-marxistického humanizmu dôraz na cnost' redukuje význam „mravnej škodlivosti“ zavedených sociálnych štruktúr a celkovo sociálnu a historickú podmienenost' mravnosti. Samotný argument akéhosi ideologického násilia je $v$ podstate lavicový predpokladá zneužívanie moci z pozície statusu toho, kto určuje obsah vzdelávania. Dokonca sme zachytili celkom neprimeranú kritiku ad hominem, ktorá bez relevantného obsahu označuje za negatívum, že koncepcia etickej výchovy si zaslúžila „pochvalnú pozornost' katolíckych kruhov“ (Valenta, 2009).

Z pohladu konzervatívcov sa zasa etická výchova javí ako prostriedok presadzovania pragmaticky orientovaného vzdelávania s dôrazom na emocionalizáciu a subjektivizáciu vyučovacích procesov, v ktorom sa strácajú duchovné tradície a hodnota klasického vzdelania. Ako sme ukázali vyššie, tento mýtus je sýtený neporozumením téz etiky cnosti implicitne prítomných v súčasnej koncepcii etickej výchovy.

Námietka sa dá chápat' aj opačne, ako epistemologická výhrada voči istému morálnemu relativizmu etiky cnosti, ktorý práve umožňuje vnášat' ideologické zámery do výchovy charakteru (hoci v česko-slovenskom diskurze nikdy takto explicitne nebola etika cnosti spájaná s relativizmom). Na ideológiu môžeme nazerat' dvomi spôsobmi:

a) Negatívne, ako na nástroj mocenského boja, ktorý nevedecky presadzuje konkrétny hodnotový systém, vytvára nový obmedzujúci jazyk, čím ohraničuje myslenie, proklamuje dielčie tvrdenia, ktoré zámerne a selektívne zakrývajú celok poznania atd'. Napr. Keller tvrdí, že

„...každá ideológia bez ohladu na to, na aké posvätné symboly sa odvoláva, môže byt' dešifrovaná ako snaha podporit' mocenské záujmy určitej skupiny l'udí vhodnou manipuláciou so symbolmi. Spoločenská skupina, ktorá má v spoločnosti dominantné postavenie, chce toto postavenie posilnit' tým, že ovláda nielen vonkajšie správanie, ale takisto myslenie členov spoločnosti...“ (Keller, 1997, s. 415);

b) Pozitívne ako na normálnu súčast' verejného diskurzu, v ktorom prichádza $k$ dialógu hodnotových stanovísk - ideí. V takom prípade je každá konzistentná sústava myšlienok, teórií a symbolov ideológiou. Marína Gálisová v časopise .týždeň v predvolebnom vydaní sa pýta: „Nie sú necnosti výsledkom úpadku, ktorý prichádza, ked’ 
sa politika zbavuje ideí? Ked' stráca morálne ukotvenie a vyvlieka sa z ideového rámca, aby nemusela za nič prijímat' zodpovednost', aby ju nebolo s čím porovnávat', pomeriavat' či hodnotit?" Hoci smeruje svoje otázky k politike, ony platia pre akúkol'vek verejnú diskusiu, aj o vzdelávaní a výchove. Môžeme teda pokojne tvrdit', že akákol'vek výchova je v pozitívnom zmysle slova ideologická.

Práve narušenie a napádanie takéhoto dialógu ideí, hoci zastreté sympatickými termínmi tolerancie, rešpektu či hodnotovo neutrálnych postojov, možno považovat' za ideológiu $v$ negatívnom zmysle, pretože zabraňuje morálnemu nároku svedomia na konflikt ideí. Idea tzv. hodnotovo neutrálnej výchovy, ktorá akejkol'vek konkurenčnej idey dáva nálepku fundamentalizmu, sa dá potom chápat’ ako „diktatúra relativizmu“ (Ratzinger, 2010).

Napätie z akejsi „indoktrinácie“ môže byt’ inherentne prítomné aj kvôli hlavnej metóde výchovy charakteru - habituácii, ktorú je možné najlepšie definovat' ako „zámerný proces vštepovania čŕt charakteru prostredníctvom opakovanej praxe pod dohl'adom zvonku“ (porov. Lawrance, 2011, in Kristjánsson, 2015, s. 51). Vzniká tak istý paradox výchovy charakteru, ktorá chce doviest' jednotlivca ku kritickému mysleniu a nezávislému morálnemu úsudku skrze vytváranie návykov $v$ správaní intencionálne spájaných s primeranými citmi. Musíme však znovu odkázat' na dimenziu fronésis, bez ktorej cnost' stráca esenciálnu kvalitu. Pri výchove charakteru nejde o presadzovanie anti-intelektuálnej metódy, ale skôr o konštruktivistické, vývinovému obdobiu primerané formovanie praktickej múdrosti, ktorá vzniká hodnotovou reflexiou opakujúcej sa pozitívnej skúsenosti.

\section{Záver}

Ciel'om tejto štúdie bolo jasnejšie ukotvit' chápanie praxe etickej výchovy v paradigme etiky cnosti a tým reagovat' na ustálené nedorozumenia, mýty a miskoncepcie vzt’ahujúce sa k predmetu etická výchova a formácii morálneho charakteru. Výchovu charakteru chápeme ako rozvoj morálnych cností, teda centrálnu dimenziu formovania človeka, len okolo ktorej sa rozvíjajú d’alšie morálne atribúty a hodnoty. Alebo inak, výchova charakteru je podmnožinou morálnej výchovy, ktorá je zasa podmnožinou hodnotovej výchovy. Ako taká teda nutne nemusí pokrývat' celé portfólio výchovy k hodnotám a ani to nie je v jej kapacitných možnostiach. Etická výchova sa implicitne zameriava na rozvoj cností, schopnost' morálnej sebareflexie a rast d'alších sociálnych zručností, ktoré umožňujú morálnym cnostiam byt' reálne aplikované do života. V tejto optike sa upresňuje tiež definícia prosociálnosti ako aristotelovsky chápaného cnostného priatel'stva. V súlade s etikou cnosti, ktorú chápeme ako učenie o naplnenom eudaimonickom živote, dôraz sa kladie predovšetkým na prax správania a praktickú múdrost', špecificky $v$ procese morálnej reflexie ako procesuálnej fázy vyučovania etickej výchovy.

Snahy o rozvoj etickej výchovy by nemali byt' ohrozené nepodloženým podceňovaním jej možností, na druhej strane však stále pretrvávajú viaceré jej reálne t’ažkosti, 
108 ktoré sme, prirodzene, nezahrnuli do výpočtu mýtov. Tieto t’ažkosti potrebujú konštruktívnu kritiku, poctivé skúmanie a úsilie o metodické skvalitnenie. Na mieste je intelektuálna skromnost' ako dôležitá akademická cnost'.

\section{Pod'akovanie}

Tvorba príspevku bola podporená grantovou agentúrou VEGA pre projekt č. 1/0056/19: Morálna reflexia ako primárny komponent výchovy charakteru v podmienkach realizácie predmetu etická výchova.

\section{Literatúra}

Alexander, R. J. (2006). Towards dialogic teaching: rethinking classroom talk. Cambridge: Dialogos.

Annas, J. (2011). Intelligent virtue. New York: Oxford University Press.

Anscombe, G. E. M. (1958). Modern moral philosophy. Philosophy, 33(1), 1-19.

Arthur, J. (2010). Of good character: exploration of virtues and values in 3-25-year-olds. Exeter: Imprint Academic.

Arthur, J., Kristjánsson, K., Harrison, T., Sanderse, W., \& Wright, D. (2017). Teaching character and virtue in schools. London: Routledge.

Bergman, R. (2002). Why be moral? A conceptual model from developmental psychology. Human Development, 45(2), 104-124.

Bierhoff, H.-W. (2002). Prosocial behaviour. New York: Taylor \& Francis.

Biesta, G. (2007). Why “what works” won't work: evidence-based practice and the democratic deficit in educational research. Educational Theory, 57(1), 1-22.

Brestovanský, M., Sádovská, A., Podmanický, I., \& Kusý, P. (2015). Charakteristiky hodnotenia a sebahodnotenia prosociálneho správania u žiakov piatych a šiestych ročníkov vybraných základných škôl. Studia Paedagogica, 20(1), 67-83.

Brestovanský, M., Kusý, P., \& Adamkovič, M. (2016). Faktorová analýza testu prosociálneho morálneho uvažovania u 11-12 ročných žiakov základných škôl. Československá psychologie, 60(5), 455-467.

Brestovanský, M. (2020a). Prosociálne morálne uvažovanie: prirodzený vývin a intencionálny rozvoj. Trnava: Typi Universitatis Tyrnaviensis-Veda SAV.

Brestovanský, M. (2020b). Meaning in life and ethical education. Spirituality Studies, 6(1), 24-33.

Buber, M. (2002). Between man and man. New York: Routledge Classics.

Carlo, G., Eisenberg, N., \& Knight, G. P. (1992). An objective measure of adolescents' prosocial moral reasoning. Journal of Research on Adolescence, 2(4), 331-349.

Curzer, H. J., Sattler, S., Dupree, D. G., \& Smith-Genthôs, K. R. (2014). Do ethics classes teach ethics? Theory and Research in Education, 12(3), 366-382.

Darnell, C. (2019). The psychological development of character: moral identity, moral emotions, moral reasoning. http://www.surveygizmo.eu/s3/90066145/Moral-identity-Moral-emotions-and-Moral-reasoning

Deci, E. L., \& Ryan, R. M. (2008). Hedonia, eudaimonia, and well-being: An introduction. Journal of Happiness Studies: An Interdisciplinary Forum on Subjective Well-Being, 9(1), 1-11.

Fabes, R. A., \& Eisenberg, N. (1998). Meta-analyses of age and sex differences in children's and adolescents' prosocial behavior. In W. Damon (Ed.), Handbook of child psychology (5th ed., Vol 3 - Social, Emotional, and Personality Development, N. Eisenberg [Ed.], s. 1-29). New York: John Wiley \& Sons. 
Frankl, V. E. (2006). Lékařská péče o duši. Brno: Cesta.

Gálisová, M. \& Jeseňák, Š. (2020, 19. január). Preč s politikou strachu. .týždeň.

Gavora, P., Mareš, J. \& Den Brok, P. (2003). Adaptácia dotazníka interakčného štýlu učitel'a. Pedagogická revue, 55(2), 126-145.

Gluchman, V. (1999). Ku koncepcii predmetu etická výchova. Pedagogická revue, 51(3), 266-272.

Gluchman, V. (1996). Etika sociálnych dôsledkov a jej kontexty. Prešov: PVT.

Grác, J. (2004). Psychológia prosociálnej výchovy v medzipredmetových vzt’ahoch. In B. Kudláčová (Ed.), Etická výchova ako súčast' univerzitného vzdelávania (s. 1-7). Trnava: PdF TU. Dostupné na https://pdf.truni.sk/zborniky/evsuv-2004/sekcia1/Grac.pdf

Grác, J. (2008). Psychológia mravnosti v teoretických a empirických analýzach. Trnava: FF TU. Grohová, V. (2018). Návrh kurikula predmetu slovenský jazyk a literatúra pre 5. ročník ZŠ $\checkmark$ kontexte školského kurikula Spojenej školy $v$ Poprade [Atestačná práca pre druhú atestáciu pedagogických zamestnancov]. Prešov: FHPV PU.

Haidt, J. (2001). The emotional dog and its rational tail: a social intuitionist approach to moral judgment. Psychological Review, 108(4), 814-834.

Haidt, J. (2003). The moral emotions. In R. J. Davidson, K. R. Scherer, \& H. H. Goldsmith (Eds.), Series in affective science. Handbook of affective sciences (s. 852-870). New York: Oxford University Press.

Keller, J. (1996). Ideologie (heslo). In H. Maříková, M. Petrusek, \& A. Vodáková (Eds.), Velký sociologický slovník (s. 415). Praha: Karolinum.

Kesebir, P., \& Kesebir, S. (2012). The cultural salience of moral character and virtue declined in twentieth century America. The Journal of Positive Psychology, 7(6), 471-480.

Kristjánsson, K. (2013) Ten myths about character, virtue, and virtue education - plus three well-founded misgivings. British Journal of Educational Studies, 61(3), 269-287.

Kristjánsson, K. (2015). Aristotelian character education. New York: Routledge.

Harrison, T., Morris, I., \& Ryan, J. (2016). Teaching character in the primary classroom. London: Sage.

MacIntyre (2007). After virtue: A study in moral theory (3rd ed.). Notre Dame: University of Notre Dame Press.

McCrae, R. R., \& Costa, P. T. (1987). Validation of the five-factor model of personality across instruments and observers. Journal of Personality and Social Psychology, 52(1), 81-90.

Morgan, B., Gulliford, L., \& Kristjánsson, K. (2014). Gratitude in the UK: A new prototype analysis and a cross-cultural comparison. The Journal of Positive Psychology, 9(4), 281-294.

Palovičová, Z. (2003). Etika cnosti a problém morálneho charakteru. Filozofia, 58(2), 75-86.

Park, N., \& Peterson, C. (2006). Moral competence and character strengths among adolescents: The development and validation of the Values in Action Inventory of Strengths for Youth. Journal of Adolescence, 29, 891-905.

Podmanický, I. (2012). Teória a prax etickej výchovy 1. Trnava: TU.

Podmanický, I., \& Brestovanský, M. (2018). Reflexia v kontexte interakčného štýlu učitela etickej výchovy. In J. Duchovičová, D. Gunišová, N. Kozárová \& R. Š. Koleňáková (Eds.), Inovatívne trendy $v$ odborových didaktikách $v$ kontexte požiadaviek praxe (s. 353-359). Nitra: PdF UKF.

Rajský, A., Podmanický, I. et al. (2016). Človek človeku. K prameňom etickej výchovy. Typi Univeristatis Tyrnaviensis - VEDA.

Rajský, A. (2020). Prečo nestačí hovorit’ o kompetenciách. Nepublikovaný príspevok v diskusii k inovácii štátneho vzdelávacieho programu.

Ratzinger, J. (2010). Chváloreč na svedomie. Trnava: Spolok Svätého Vojtecha.

Rest, J., Narvaez, D., Bebeau, M., \& Thoma, S. (1999). A neo-Kohlbergian approach: The DIT and schema theory. Educational Psychology Review, 11(4), 291-324.

Rosch, E. (1975). Cognitive representations of semantic categories. Journal of Experimental Psychology: General, 104(3), 92-233.

Seligman, M. E. P., \& Csikszentmihalyi, M. (2000). Positive psychology: an introduction. American Psychologist, 55(1), 5-14. 
110 Sevinc, G., \& Spreng, R. N. (2014) Contextual and perceptual brain processes underlying moral cognition - a quantitative meta-analysis of moral reasoning and moral emotions. PLOS ONE, 9(2): e87427.

Schooler, J. W. (2014). Metascience could rescue the 'replication crisis'. Nature, 515(7525), 9.

Šed’ová, K., Švaříček, R., Sedláček, M., \& Šalamounová, Z. (2016). Jak se učitelé učí. Cestou profesního rozvoje k dialogickému vyučování. Brno: Masarykova univerzita.

Štech, S. (2013). Když je kurikulární reforma evidence-less. Pedagogická orientace, 23(5), 615-633.

Thoma, S., Derryberry, W. P., \& Crowson, H. M. (2013). Describing and testing an intermediate concept measure of adolescent moral thinking. European Journal of Developmental Psychology, 10(2), 239-252.

Valenta, J. (2009). Budeme mít předmět etická výchova? Učitelské noviny, 112(6), 18-19.

Valica, M., Fridrichová, P., \& Rohn, T. (2014). Evalvácia a modifikácia modelov výučby etickej výchovy a kompetenčného profilu učitel'a etickej výchovy. Banská Bystrica: Pedagogická fakulta UMB.

Vašičková, S. (2015). Zvyšovanie kvality vzdelávania na základných a stredných školách $s$ využitím elektronického testovania [Správa z merania interakčného štýlu učitel'a]. Bratislava: NÚCEM.

Warden, D., Cheyne, B., Christie, D., Fitzpatrick, H., \& Reid, K. (2003). Assessing children's perceptions of prosocial and antisocial peer behaviour. Educational Psychology, 23(5), 547-567.

Wiesenganger, M. (2018). Pomoc a cnost' v Teologickej sume Tomáša Akvinského. In A. Rajský \& M. Wiesenganger (Eds.), Pomoc druhému na ceste cnosti. $K$ filozoficko-etickým aspektom prosociálnosti. Trnava: Typi Universitatis Tyrnaviensis.

Zelina, M. (1992, 21. august). Etická výchova alebo psychológia prosociálnej výchovy? Smena na nedelu.

Martin Brestovanský

Pedagogická fakulta Trnavskej univerzity v Trnave martin.brestovansky@truni.sk 